\title{
Acute haemodynamic effects of practolol in patients with idiopathic hypertrophic subaortic stenosis ${ }^{1}$
}

\author{
Harvey J. Matlof and Donald C. Harrison \\ From Cardiology Division, Stanford University School of Medicine, Stanford, California 94305, U.S.A.
}

Ten patients with idiopathic hypertrophic subaortic stenosis were studied with right and transseptal left heart catheterization. All patients had the expected increases in subvalvular systolic gradients with isoprenaline infusion, amyl nitrite inhalation, exercise, and performance of the Valsalva manoeuvre. These stimulatory procedures were repeated after intravenous infusion of practolol (600 or $900 \mu \mathrm{g} / \mathrm{kg}$ ). This resulted in partial amelioration of exercise and isoprenaline-induced gradient augmentation, with no effect on resting gradients. These data suggest that practolol at doses of 600 to $900 \mu \mathrm{g} / \mathrm{kg}$ is less effective than $150 \mu \mathrm{g} / \mathrm{kg}$ of propranolol, which has been reported in previous studies of patients with idiopathic hypertrophic subaortic stenosis to block induction of gradients more completely.

Idiopathic hypertrophic subaortic stenosis is a wellrecognized syndrome in which functional subvalvular outflow tract obstruction may be variable and may be modified by various physiological and pharmacological manoeuvres (Wigle et al., 1965; Whalen et al., 1963; Braunwald and Ebert, 1962; Braunwald et al., 1964; Brockenbrough, Braunwald, and Morrow, 196I). Outflow tract obstruction has been shown to increase with isoprenaline infusion (Wigle et al., 1965; Braunwald and Ebert, 1962), amyl nitrite inhalation (Wigle et al., 1965), and performance of the Valsalva manoeuvre (Braunwald et al., 1964). Narrowing of aortic pulse pressure with increase in left ventricular-aortic (LV-Ao) gradients has been noted in post-extrasystolic cycles (Brockenbrough et al., 196I). Since Harrison's studies with nethalide in 1964 (Harrison et al., 1964), betaadrenergic blockade has been one of the preferred modes of medical treatment of patients with idiopathic hypertrophic subaortic stenosis. Several investigators have reported significant improvement in terms of effort tolerance and decrease in angina pectoris after the prolonged oral administration of propranolol (Cohen and Braunwald, I968; Adelman et al., 1970; Rosenblum et al., 1967; Cherian et al., 1966; Flamm, Harrison, and Hancock, 1968). Propranolol has also been shown to ameliorate the increases in subaortic obstruction caused by exercise

Received 21 July 1972.

1 This work was supported in part by N.I.H. Grants and a grant from the National Aeronautics and Space Administration. or isoprenaline infusion (Cherian et al., 1966; Flamm et al., 1968).

Practolol is a new cardioselective beta-adrenergic blocking agent which differs from propranolol in several respects. Unlike the latter, practolol is cardioselective with little or no effect on peripheral vasculature or bronchial smooth muscle (Dunlop and Shanks, 1968). Practolol lacks 'quinidine-like' or 'membrane-like' properties found in propranolol, and thus may exert less direct myocardial depression (Dunlop and Shanks, 1968; Somani and Laddu, I969). In addition, practolol possesses mild intrinsic sympathetic properties (Dunlop and Shanks, 1968; Barrett and Carter, 1970; Wale, Pun, and Rand, 1969). These properties suggest that practolol may have fewer side effects than propranolol in causing airway obstruction and for producing congestive heart failure.

Although practolol has been employed widely for the treatment of arrhythmias and angina in patients with ischaemic heart disease (Jewitt, Mercer, and Shillingford, 1969; Gent, Davis, and McDonald, 1970; Coltart, 1970; Wilson et al., 1969; Atkins, Blomqvist, and Cohen, 1970), there are few reports regarding its use in patients with idiopathic hypertrophic subaortic stenosis. Webb-Peploe et al. reported that practolol in doses of 20 to $40 \mathrm{mg}$ intravenously did not significantly alter outflow tract obstruction at rest or with stress (Webb-Peploe, Croxson, and Oakley, 197I), but that left ventricular end-diastolic pressure was lowered after practolol administration (Webb-Peploe et al., 1970, 1971). 
Since practolol is a promising beta-adrenergic blocking agent with certain theoretical advantages over propranolol, this study was designed to evaluate its haemodynamic effects in patients with idiopathic hypertrophic subaortic stenosis. The results of studies in ro such patients are outlined in this report.

\section{Methods}

The ro patients represent all those studied in our laboratory between October 1970 and July 1971. All patients underwent right and transseptal left heart catheterization after sedation with $100 \mathrm{mg}$ intramuscular quinalbarbitone. The Brockenbrough catheter used for the transseptal procedure was positioned just across the mitral valve into the left ventricular cavity. This position was tested by withdrawing into the left atrium and readvancing to the first position where undistorted left ventricular pressure curves were obtained. An arterial catheter was inserted by the Seldinger technique into the aorta for simultaneous recording of left ventricular (LV) and aortic (Ao) pressures. LV-Ao gradients were expressed as peak-to-peak differences.

After measurement of resting haemodynamic parameters, 9 patients performed the Valsalva manoeuvre, 9 inhaled amyl nitrite, and 9 received a bolus injection of isoprenaline $(3 \mu \mathrm{g})$. Before each such manoeuvre, con- trol measurements of LV-Ao gradients were made and, after these, the gradients were measured at the point of peak effect. Cardiac outputs at rest and supine exercise using a bicycle ergometer were estimated by indocyanine green dye dilution techniques in 7 patients and by the Fick method in 2.

After these measurements, practolol was given intravenously over a ro-minute period: seven patients received $600 \mu \mathrm{g} / \mathrm{kg}$ and three $900 \mu \mathrm{g} / \mathrm{kg}$. After a 20-minute rest interval, the procedure described above was repeated. Exercise loads and drug challenges were the same for each patient before and after drug administration. All exercise determinations were made between the fifth and tenth minutes of sustained exercise. A $t$ test for paired data was used to determine statistical significance in comparing pre- and post-practolol effects.

\section{Results}

The resting haemodynamic data before and after practolol administration are shown on Table $\mathrm{I}$. Two of the patients had no LV-Ao gradient at rest, while the remaining 8 had resting gradients ranging from 10 to $88 \mathrm{mmHg}$. All patients displayed increases in gradients with the Valsalva manoeuvre, amyl nitrite inhalation, and isoprenaline injection (Table 2). In addition, increased gradients were uniformly noted in postextrasystolic contractions. Thus,

TABLE I Resting haemodynamics before and after practolol infusion

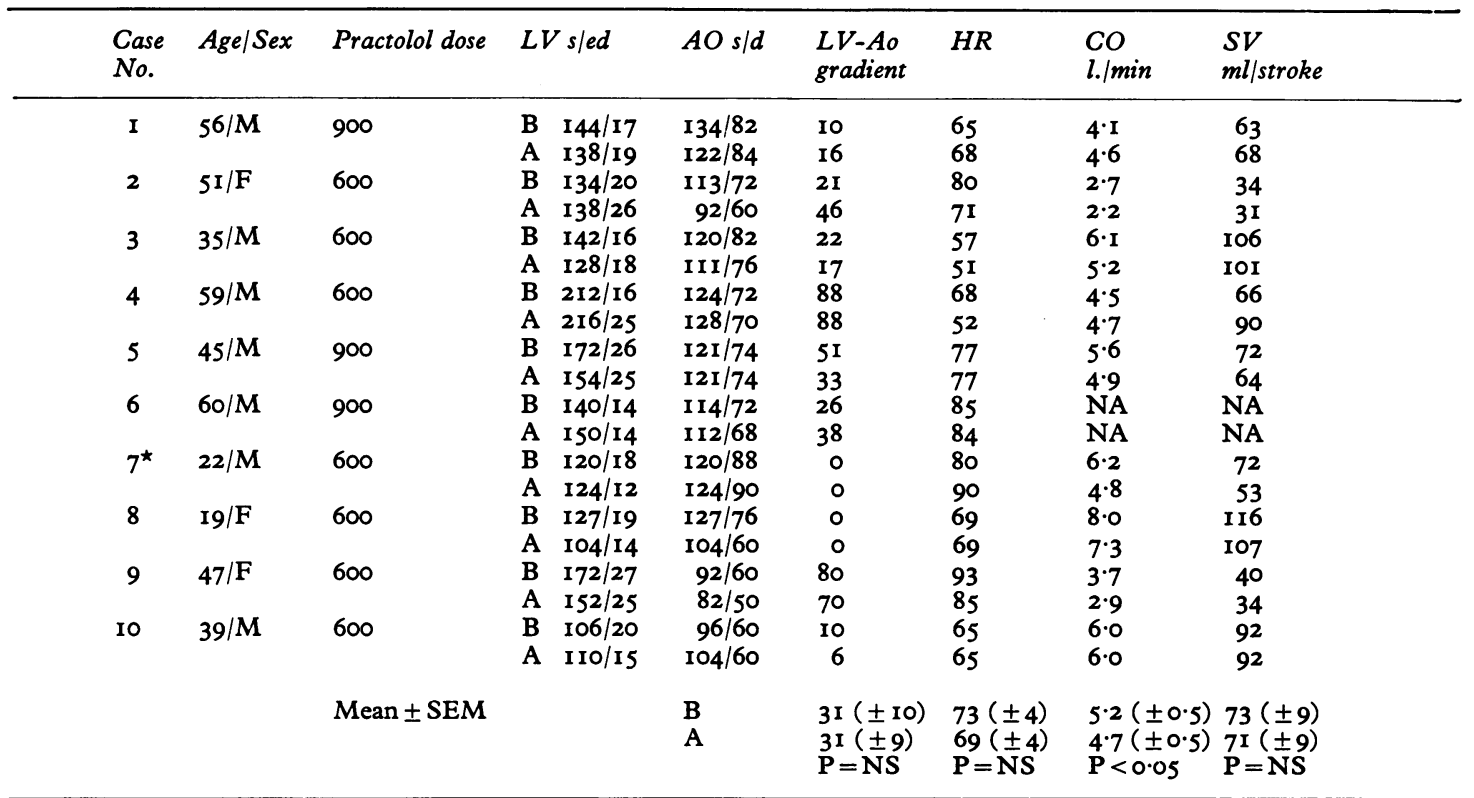

^ Patient developed rapid atrial fibrillation just before practolol infusion, which persisted for rest of study.

Abbreviations : $\mathrm{LV}=$ left ventricular pressure $(\mathrm{mmHg})$; $\mathrm{LV}$-Ao = left ventricular-aortic; $\mathrm{HR}=$ heart rate per minute ; $\mathrm{CO}=$ cardiac output $(1 . / \mathrm{min}) ; \mathrm{SV}=$ stroke volume $(\mathrm{ml} / \mathrm{stroke}) ; \mathrm{NA}=$ not available; $\mathrm{NS}=$ not significant; $\mathrm{B}=$ before practolol; $\mathrm{A}=\mathrm{after}$ practolol. 
TABLE 2 Increases in left ventricular-aortic gradients induced by stimulatory manoeuvres, before and after practolol

\begin{tabular}{|c|c|c|c|c|c|c|c|c|}
\hline \multirow[t]{2}{*}{ Case No. } & & \multirow{2}{*}{$\begin{array}{l}\text { Valsalva } \\
\Delta \text { grad. }\end{array}$} & \multirow{2}{*}{$\begin{array}{l}\text { Post VPC } \\
\Delta \text { grad. }\end{array}$} & \multirow{2}{*}{$\begin{array}{l}\text { Amyl } \\
\Delta \text { grad. }\end{array}$} & \multicolumn{2}{|l|}{ Isoprenaline } & \multicolumn{2}{|l|}{ Exercise } \\
\hline & & & & & $\Delta$ grad. & $\Delta H R$ & $\Delta$ grad. & $\Delta H R$ \\
\hline \multirow[t]{2}{*}{$\mathbf{I}$} & B & 48 & 86 & 49 & 122 & $3 I$ & $3 I$ & $4 I$ \\
\hline & A & 54 & 80 & 56 & 75 & 14 & 26 & 30 \\
\hline \multirow[t]{2}{*}{2} & B & 23 & 31 & - & - & - & 4 & $3 I$ \\
\hline & A & 2 & 30 & - & - & - & - IO & I9 \\
\hline \multirow[t]{2}{*}{3} & B & 36 & $4 I$ & 37 & 92 & 26 & I4 & 29 \\
\hline & A & 20 & 6 & 25 & 72 & 12 & I3 & I7 \\
\hline \multirow[t]{2}{*}{4} & B & 74 & 104 & 76 & 80 & 19 & I6 & 22 \\
\hline & A & 84 & 94 & 56 & 86 & 20 & 0 & 23 \\
\hline \multirow[t]{2}{*}{5} & B & 54 & 37 & 19 & 42 & 16 & I6 & 13 \\
\hline & A & 32 & 79 & 32 & 40 & 5 & $-\mathrm{I} 6$ & 3 \\
\hline \multirow[t]{2}{*}{6} & B & - & 66 & 44 & 106 & 26 & 6 & I3 \\
\hline & A & - & 66 & 46 & 32 & 5 & -14 & I I \\
\hline \multirow[t]{2}{*}{7} & B & I I & 78 & 76 & 76 & 28 & 28 & 30 \\
\hline & A & I4 & 25 & 54 & 13 & 5 & 29 & 60 \\
\hline \multirow[t]{2}{*}{8} & B & 7 & 30 & 4 & 20 & II & 15 & I4 \\
\hline & A & 0 & 6 & 0 & 0 & 6 & 16 & 2 \\
\hline \multirow[t]{2}{*}{9} & B & 19 & 56 & 14 & 42 & 28 & 4 & I5 \\
\hline & A & 13 & 70 & -5 & -5 & I5 & -8 & 10 \\
\hline \multirow[t]{2}{*}{ I0 } & B & 46 & 80 & 58 & 107 & 45 & - & - \\
\hline & A & 46 & 72 & 53 & 83 & 26 & 一 & - \\
\hline $\begin{array}{l}\text { Mean } \\
( \pm \text { SEM })\end{array}$ & $\begin{array}{l}\text { B } \\
\text { A }\end{array}$ & $\begin{array}{l}35 \cdot 3 \pm 7 \cdot 3 \\
25 \cdot 3 \pm 9 \cdot 3 \\
P=N S\end{array}$ & $\begin{array}{l}60.9 \pm 8.2 \\
52 \cdot 8 \pm 10.3 \\
P=N S\end{array}$ & $\begin{array}{l}38.6 \pm 7.6 \\
34.7 \pm 7.4 \\
P=N S\end{array}$ & $\begin{array}{l}76.6 \pm \text { II } .6 \\
44.6 \pm \text { II } .8 \\
P<0.01\end{array}$ & $\begin{array}{l}24 \pm 3.9 \\
12.9 \pm 2.7 \\
P<0.01\end{array}$ & $\begin{aligned} 16.6 \pm 3.1 \\
7 \cdot 2 \pm 5.4 \\
P<0.05\end{aligned}$ & $\begin{array}{l}22.0 \pm 3.8 \\
15.6 \pm 3.0 \\
P<0.05\end{array}$ \\
\hline
\end{tabular}

Abbreviations: $B=$ before practolol; $A=$ after practolol; $V P C=$ ventricular premature contractions; $H R=$ heart rate; NS $=$ not significant.

all to patients fulfilled completely the diagnostic criteria for idiopathic hypertrophic subaortic stenosis.

The mean resting cardiac output for the group was $5.2 \mathrm{l} . / \mathrm{min}$, which decreased slightly to $4.7 \mathrm{l}$./min after the administration of practolol $(P<0.05)$. Resting stroke volume decreased minimally from 73.4 to $7 \mathrm{I} \cdot \mathrm{I} \mathrm{ml}$, while heart rate went from 73.2 to 69.1 beats a minute. The changes in stroke volume and rate were not statistically significant.

The mean resting gradient was unaffected by practolol $(30.8 \mathrm{mmHg}$ before and $31 \cdot 4$ after). The response to amyl nitrite inhalation was not altered after practolol (Fig. I). Before practolol administration, the LV-Ao gradient after amyl nitrite rose from 33 to $7 \mathrm{r} \cdot 6 \mathrm{mmHg}$. After practolol, the gradient rose from 32.3 to $66.4 \mathrm{mmHg}$. The pre- and postpractolol responses were similar and statistically undistinguishable (Fig. 2).

Before practolol, isoprenaline injection produced an average gradient increase of $76.6 \mathrm{mmHg}$, from 38. I to I $14.4 \mathrm{mmHg}$ (Fig. 3 and 4). The heart rate increased by 25 beats a minute from a rate of $7 \mathrm{I} \cdot 6$ to $96 \cdot 9$. After practolol, the average gradient rose only $44.6 \mathrm{mmHg}$, rising from 30.2 to $74.2 \mathrm{mmHg}$, and the heart rate increased from $67 \cdot 2$ to $80 \cdot \mathrm{I}$. The blunting of both gradient and heart rate responses was significant $(P<0.01)$. There was, however, individual variation among patients. Two patients (Cases 8 and 9) showed complete block of the isoprenaline stimulation. Five patients (Cases $1,3,6$, 7, and 10) demonstrated partial amelioration, and 2 patients (Cases 4 and 5) had no alteration of the isoprenaline effect after practolol. One of these latter 2 patients (Case 5) received the larger dose of 900 $\mu \mathrm{g} / \mathrm{kg}$. His heart rate increased by 5 beats a minute with isoprenaline injection after practolol, whereas it had increased by 16 beats a minute before practolol. The other non-responder (Case 4) received 600 $\mu \mathrm{g} / \mathrm{kg}$ of practolol and had no block of heart rate response to isoprenaline after practolol.

The response of the systolic gradient to supine exercise is illustrated in Fig. 5 and 6. Before practolol, exercise induced a mean rise of $16.6 \mathrm{mmHg}$ in LV-Ao gradients, with an associated increase in heart rate of 22 beats a minute. After practolol there was a small increase in both gradient $(7.2 \mathrm{mmHg})$ and heart rate ( 15.6 beats $/ \mathrm{min}$ ). Both of these changes were significant $(P<0.05)$. Again, there was individual variation, with 3 patients (Cases 3,7 , and 8) showing no difference in gradient response after practolol. 


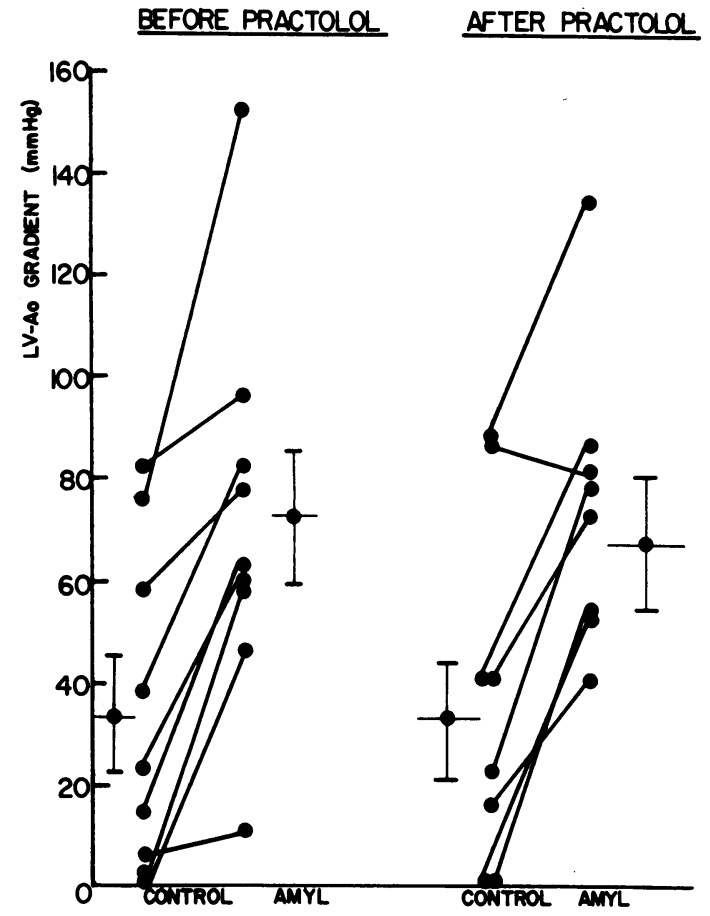

FIG. I Left ventricular-aortic gradients after amyl nitrite inhalation, before and after practolol infusion. Group means \pm I SEM are included.

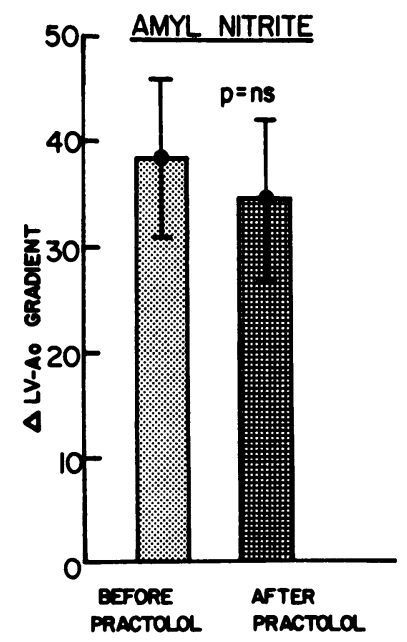

FIG. 2 Change in left ventricular-aortic gradients induced by amyl nitrite inhalation, before and after practolol infusion.

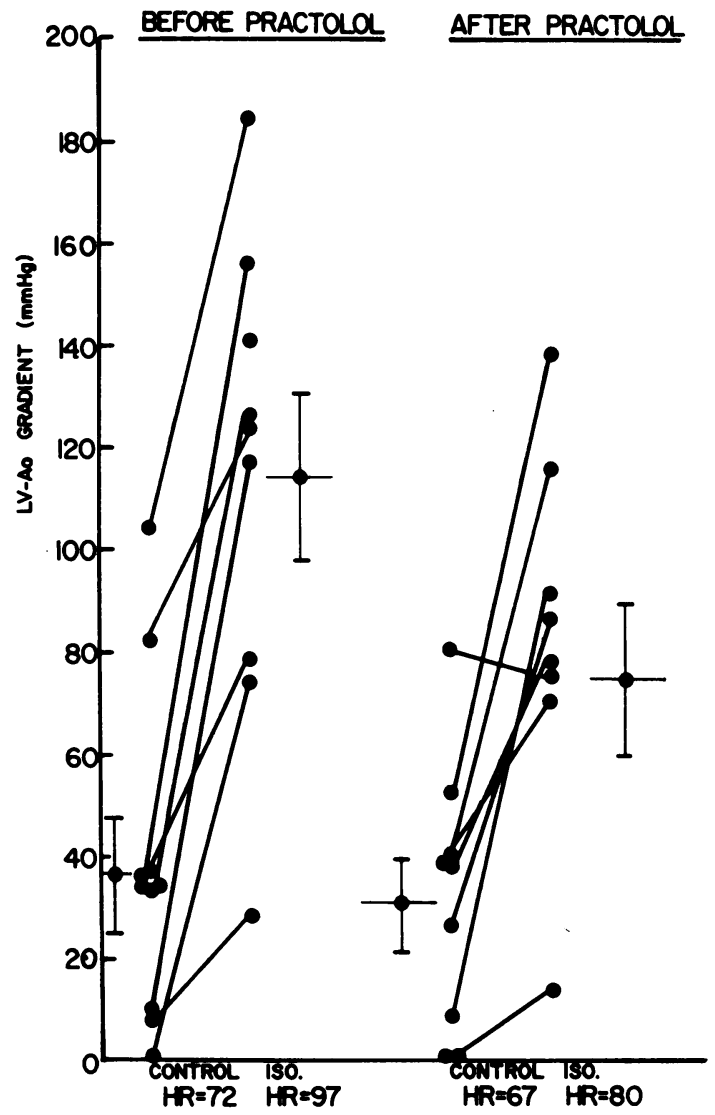

FIG. 3 Left ventricular-aortic gradients following isoprenaline, before and after practolol infusion.

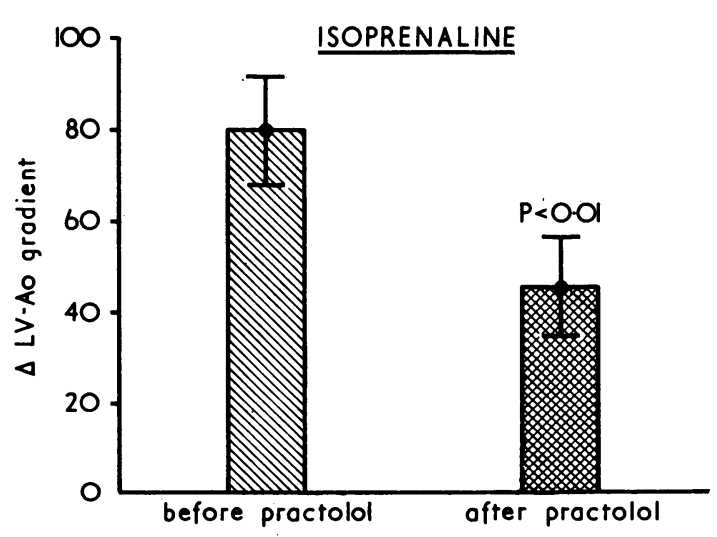

FIG. 4 Change in left ventricular-aortic gradients induced by isoprenaline, before and after practolol infusion. 
All patients had the expected gradient responses to the Valsalva manoeuvre as well as postextrasystolic augmentation of LV-Ao gradients. These two responses were not affected by practolol (Table 2).

\section{Discussion}

The data obtained in this study indicate that practolol in acutely administered doses of 600 to 900

$\mu \mathrm{g} / \mathrm{kg}$ provides only partial inhibition of reactive increases in subvalvular gradients in patients with idiopathic hypertrophic subaortic stenosis. Harrison et al. (1964) first reported the effects of the betablocking agent, nethalide, in patients with this lesion. In that study, $1.5 \mathrm{mg} / \mathrm{kg}$ of nethalide completely blocked the increase in gradient produced by isoprenaline. Similar results were reported by Cherian et al. (1966) in a group of patients given nethalide $(2.5 \mathrm{mg} / \mathrm{kg}$ ) or propranolol (150 $\mu \mathrm{g} / \mathrm{kg}$ ).

Practolol had no effect on resting gradients in the present study, whereas Flamm et al. (1968) showed that propranolol in doses of $150 \mu \mathrm{g} / \mathrm{kg}$ decreased resting LV-Ao gradients.

In a previous report from this laboratory (Flamm et al., I968), I I patients with idiopathic hypertrophic subaortic stenosis were studied before and after the intravenous administration of propranolol (150 $\mu \mathrm{g} / \mathrm{kg}$ ). The study design was identical to the present report and showed that propranolol, given acutely, produced blockade of the isoprenaline augmentation of LV-Ao gradients.

The results of the present study differ in that practolol seemed to produce only partial blockage of the isoprenaline effect on LV-Ao gradients. This was associated with only a partial block of isoprenaline's heart rate effect as well. In addition, the exercise-induced tachycardia and gradient were only partially ameliorated by practolol in the present study, with 3 patients showing no practolol effect. One can conclude, therefore, that acute intravenous doses of 600 to $900 \mu \mathrm{g} / \mathrm{kg}$ of practolol provide less amelioration of subvalvular obstruction than 150 $\mu \mathrm{g} / \mathrm{kg}$ of intravenous propranolol.

The dose of practolol chosen for this study was aimed at a level four to six times the amount of propranolol $(150 \mu \mathrm{g} / \mathrm{kg}$ ) which was known to block the isoprenaline effect in patients with idiopathic hypertrophic subaortic stenosis. This ratio was based on several studies in animals and humans. Dunlop and Shanks (I968) reported that practolol's betablocking capability was one-third to one-fourth as potent as propranolol in a dog study. Barrett concluded that the practolol to propranolol ratio was $I: 3$ in a study performed on rats (Barrett and Carter, 1970). Wale showed that the dose of practolol required to produce a 50 per cent reduction of isoprenaline-induced tachycardia was seven times as great as propranolol (Wale et al., 1969). A similar ratio of $\mathrm{I}: 7$ was reported in a dog study by Hashimoto et al. (1969).

Fitzgerald and Scales (1968) felt that the practolol to propranolol dose ratio in humans was about 3 or 4 to $I$, based on the amount required to reduce exercise tachycardia by 30 per cent. Three other studies dealing with humans with angina pectoris indicated 
that the amount of practolol required to reduce angina and prolong treadmill exercise tolerance was about two to four times as great as propranolol (Coltart, 1970; Wilson et al., 1969; Atkins et al., 1970).

Thus, in spite of using what appeared to be equivalent doses of practolol, the degree of protection from catecholamine-induced gradient increases was only partial and probably less effective than propranolol in our group of patients. Perhaps our observations can be explained by another aspect of the pharmacology of practolol. Dunlop and Shanks (1968) noted that the shape of the dose response curve for practolol was flattened at high dose levels. In contrast, propranolol had a dose response curve which did not flatten at higher doses. Thus, most comparisons made between the two drugs are based on equivalent levels of partial beta blockade, at a point where the two dose response curves are roughly parallel. If this hypothesis is true, one might predict that our patients would still have been only partially protected at higher doses. Unfortunately, no human studies are available on the adequacy of beta blockade with intravenous practolol at doses higher than those used in the present study.

Another possible explanation for the mild amelioration of effect of practolol is that it may have produced a mild level of beta-adrenergic stimulation, thereby reducing its effects in blocking beta receptors (Dunlop and Shanks, 1968; Barrett and Carter, 1970; Wale et al., 1969). The observation that resting heart rate was reduced insignificantly and that left ventricular end-diastolic pressures did not rise may be due to the dual blocking and stimulating actions of practolol.

The fact that practolol does not block the peripheral vasodilatory effects of isoprenaline (Dunlop and Shanks, 1968) offers an additional reason for its apparent inferiority to propranolol in patients with idiopathic hypertrophic subaortic stenosis. If isoprenaline results in decreased peripheral vascular resistance, this would decrease outflow tract wall tension and increase subvalvular gradients (Wigle et al., 1965). Propranolol blocks the peripheral as well as cardiac effects of isoprenaline, both of which result in lowering of outflow tract obstruction. Practolol, on the other hand, lacks the capability of blocking the peripheral effects of isoprenaline. This theoretically would offset the cardiac betaadrenergic blockade and lessen the effect in ameliorating subvalvular gradient stimulation.

There are three aims of beta-adrenergic blockade in patients with idiopathic hypertrophic subaortic stenosis: the prevention of paroxysmal atrial arrhythmias, the reduction of anginal symptoms, and amelioration of stress-induced increases in outflow tract obstruction. Practolol dosage levels used in this study might be effective in prevention of arrhythmias and angina (Jewitt et al., 1969; Gent et al., 1970; Coltart, 1970; Wilson et al., 1969; Atkins et al., 1970), but were not as effective as propranolol in reducing outflow tract obstruction. We believe that reduction of subaortic obstruction may be important in ameliorating ventricular hypertrophy, which, in turn, would prevent further obstruction (Flamm et al., 1968). The interruption of this vicious cycle is the rationale for treating the asymptomatic patient with idiopathic hypertrophic subaortic stenosis. Since propranolol appears to be more effective than practolol in this respect, it seems to be the preferred agent for treatment.

\section{References}

Adelman, A. G., Shah, P. M., Gramiak, R., and Wigle, E. D. (1970). Long-term propranolol therapy in muscular subaortic stenosis. British Heart fournal, 32, 804.

Atkins, J. M., Blomqvist, G., and Cohen, L. S. (1970). Comparative study of beta-adrenergic blocking agents on exercise tolerance in ischemic heart disease (abstract). Circulation, 42, Suppl. III, 132.

Barrett, A. M., and Carter, J. (1970). Comparative chronotropic activity of beta-adrenoreceptive antagonists. British fournal of Pharmacology, 40, 373.

Braunwald, E., and Ebert, P. A. (1962). Hemodynamic alterations in idiopathic hypertrophic subaortic stenosis induced by sympathomimetic drugs. American fournal of Cardiology, 10, 489.

Braunwald, E., Oldham, H. N., Ross, J., Linhart, J. W., Mason, D. T., and Fort, L. (1964). The circulatory response of patients with idiopathic hypertrophic subaortic stenosis to nitroglycerin and to the Valsalva maneuver. Circulation, 29, 422.

Brockenbrough, E. C., Braunwald, E., and Morrow, A. G. (196I). A hemodynamic technic for the detection of hypertrophic subaortic stenosis. Circulation, 23, 189.

Cherian, G., Brockington, I. F., Shah, P. M., Oakley, C. M., and Goodwin, J. F. (1966). Beta-adrenergic blockade in hypertrophic obstructive cardiomyopathy. British Medical fournal, 1, 895.

Cohen, L. S., and Braunwald, E. (1968). Chronic betaadrenergic receptor blockade in the treatment of idiopathic hypertrophic subaortic stenosis. Progress in Cardiovascular Diseases, II, 2 I I.

Coltart, D. J. (1970). A comparison of the effects of propranolol and practolol on the exercise tolerance in angina pectoris. British fournal of Pharmacology, 40, 147.

Dunlop, D., and Shanks, R. G. (I968). Selective blockade of adrenoreceptive beta receptors in the heart. British fournal of Pharmacology, 32, 201.

Fitzgerald, J. D., and Scales, B. (1968). Effect of a new betablocking agent (ICI 50,172) on heart rate in relation to its blood levels. Internationale Zeitschrift für klinische Pharmakologie, Therapie und Toxikologie, 1, 467.

Flamm, M. D., Harrison, D. C., and Hancock, E. W. (1968). Muscular subaortic stenosis, prevention of outflow tract obstruction with propranolol. Circulation, 38, 846.

Gent, G., Davis, T. C., and McDonald, A. (1970). Practolol in treatment of supraventricular cardiac dysrhythmias. British Medical fournal, $\mathbf{x}, 533$. 
Harrison, D. C., Braunwald, E., Glick, G., Mason, D. T., Chidsey, C. A., and Ross, J. (1964). Effects of betaadrenergic blockade on the circulation, with particular reference to observations in patients with hypertrophic subaortic stenosis. Circulation, 29, 84.

Hashimoto, K., Ohkuda, K., Chiba, S., and Taira, N. (1969). Beta-adrenergic blocking effect of dichloroisoprenaline (DCI) (H56/28, ICI 50,172, LB46), methoxamine (MJ 1999) and propranolol on the sinus node activity of the dog heart. Experientia, 25, II56.

Jewitt, D. E., Mercer, C. J., and Shillingford, J. P. (I969). Practolol in the treatment of cardiac dysrhythmias due to acute myocardial infarction. Lancet, 2, 227.

Rosenblum, R., Frieden, J., Delman, A. J., and Berkowitz, W. D. (1967). Long-term propranolol therapy in patients with idiopathic hypertrophic subaortic stenosis (abstract). Circulation, 36, Suppl. II, 226.

Somani, P., and Laddu, A. R. (1969). Blockade of cardiac effects of isoproterenol by 4-(2-hydroxy-3-isopropylaminoproproxy)-acetanilide (ICI50, 172). Fournal of Pharmacology and Experimental Therapeutics, 170, 72.

Wale, J., Pun, L. Q., and Rand, M. J. (1969). The effects of ICI 50,172, propranolol, pronethalol and MJ 1999 on $\beta$-receptors. European fournal of Pharmacology, 8, 25.
Webb-Peploe, M., Croxson, R. S., and Oakley, C. M. (1971). Beta-adrenergic blockade with practolol in hypertrophic obstructive cardiomyopathy (abstract). British Heart fournal, 33, 143 .

Webb-Peploe, M. M., Croxson, R. S., Oakley, C. M., and Goodwin, J. F. (1970). Cardioselective beta adrenergic blockade in hypertrophic cardiomyopathy (abstract). American fournal of Cardiology, 26, 665.

Whalen, R. E., Cohen, A. I., Sumner, R. G., and McIntosh, H. D. (1963). Demonstration of the dynamic nature of idiopathic hypertrophic subaortic stenosis. American fournal of Cardiology, II, 8.

Wigle, E. D., David, P. R., Labrosse, C. J., and McMeekan, J. (1965). Muscular subaortic stenosis. The interrelation of wall tension, outflow tract 'distending pressure' and orifice radius. American fournal of Cardiology, 15, 761.

Wilson, A. G., Brooke, O. G., Lloyd, H. J., and Robinson, B. F. (1969). Mechanism of action of $\beta$-adrenergic receptor blocking agents in angina pectoris. Comparison of action of propranolol with dexpropranolol and practolol. British Medical fournal, 4, 399.

Requests for reprints to Dr. Donald C. Harrison, Cardiology Division, Stanford University Medical Center, Stanford, California 94305, U.S.A. 